DOI: $10.25283 / 2223-4594-2018-2-94-106$

УДК 55:551.462.32(268.35+922.1)

\title{
БАЗАЛЬТОИДНЫЙ МАГМАТИЗМ
}

\section{И ПРОБЛЕМА ГАЗОНОСНОСТИ ВОСТОЧНО- БАРЕНЦЕВСКОГО МЕГАБАССЕЙНА}

\author{
Э. В. Шипилов \\ ФГБНУ Полярный геофизический институт (Мурманск, Российская Федерация)
}

\author{
Статья поступила в редакцию 12 апреля 2018 г.
}

Рассмотрены проявления юрско-мелового базальтоидного магматизма в осадочном чехле Баренцевоморской континентальной окраины, зафиксированные различными методами геолого-геофизических исследований. Аномальные сейсмические горизонты, обусловленные пластовыми магматическими телами силлов, расположенными в терригенных комплексах, прослеживаются в плане в виде языка от архипелага Земля Франиа-Иосифа далеко на юг вдоль депоцентральной зоны ВосточноБаренцевской троговой системы (мегабассейна) с трансформированной земной корой. В результате исследований магматическая провинция Баренцева моря была оконтурена. Сейсмостратиграфический анализ и определение абсолютного возраста базальтоидных образований с высокой вероятностью указывают на то, что локальные структуры месторождений углеводородов Лудловской группы месторождений углеводородов (так называемого Штокманско-Лунинского порога) формировались под воздействием процессов интрузивной магматической деятельности.

Ключевые слова: Восточно-Баренцевский мегабассейн, базальтоидный магматизм, сейсмические разрезы, антиклинальные структуры, месторождения углеводородов, тектономагматический фактор.

\section{Введение}

В строении Баренцевоморской континентальной окраины и ее бассейнов заметную роль играет базальтоидный магматизм. Его проявления отмечены геологическим картированием в различных стратиграфических подразделениях разрезов близлежащего сухопутного (материкового и островного) обрамления исследуемого региона. Фиксируются они и по данным морских геолого-геофизических работ в осадочных комплексах ряда бассейнов.

Установлено несколько стратиграфических и межформационных уровней магматизма, близкого по составу к базитовым трапповым формациям: преимущественно силурийский, позднедевонскораннекарбоновый, позднепермско-раннетриасовый, юрско-меловой и кайнозойский [1]. Но наиболее широко и отчетливо среди них проявляется ареал, связанный с юрско-меловым тектономагматическим этапом. Распространение этих магматогенных образований отмечается на архипелагах Шпицберген и Земля Франца-Иосифа (ЗФИ) и окружающем их шельфе, в Южно- и Северо-Баренцевской впадинах,

(๐) Шипилов Э. В., 2018 в троге Святой Анны и других районах (рис. 1). В этой связи представляется, что изучение этого тектономагматического фактора имеет первостепенное значение не только для реконструкции истории геологического развития как самой окраины, так и раннего периода становления Арктического океана, но также в плане его стрессового влияния на созревание $C_{\text {орг }}$ в нефтематеринских толщах, фазовый состав углеводородов (УВ), формирование ловушек и скопление в них флюидов.

\section{Баренцевоморская магматическая провинция: общая характеристика}

Проявления юрско-мелового базальтоидного магматизма в осадочном чехле Баренцевоморской континентальной окраины зафиксированы различными методами геологических и геофизических исследований. Однако в большинстве опубликованных как отечественных, так и особенно зарубежных работ в качестве основных районов магматизма рассматриваются лишь его проявления, установленные на архипелагах ЗФИ и Шпицберген в ходе различных геологических съемок и бурения параметрических скважин. Соответственно и ареал магматизма 


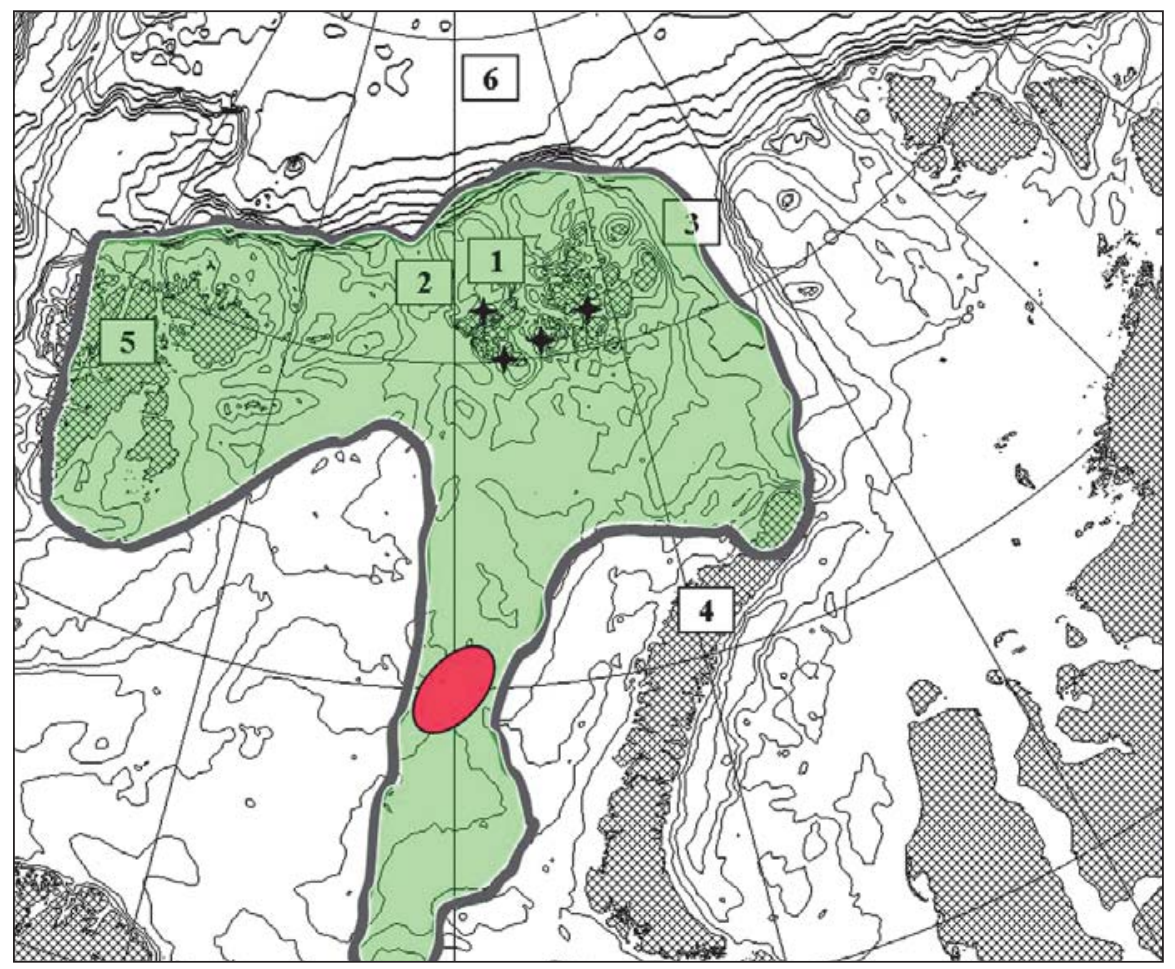

Рис. 1. Батиметрия и ареал юрско-мелового базальтоидного магматизма Баренцевоморской континентальной окраины: красный овал - Лудловская группа месторождений углеводородов (Штокманское, Лудловское, Ледовое); звездочки - места отбора проб базальтов; 1 - архипелаг Земля Франца-Иосифа, 2 - желоб Франц-Виктория, 3 - желоб Святой Анны, 4 - Новая Земля, 5 - Шпицберген, 6 - котловина Нансена Евразийского бассейна

ограничивался преимущественно периметром площади, занятой архипелагами.

По результатам нашей интерпретации морских геолого-геофизических данных так называемые аномальные сейсмические горизонты, обусловленные базальтоидными интрузиями - силлами [2-4], насыщают разрез терригенных отложений и в плане прослеживаются от архипелага ЗФИ в виде языка далеко на юг вдоль Восточно-Баренцевской троговой системы, придерживаясь полосы ее депоцентра с трансформированной утоненной земной корой [5]. На многочисленных сейсмических разрезах через Южно- и Северо-Баренцевскую впадины достаточно отчетливо наблюдается, как с юга на север пакеты интрузивных базальтоидных тел занимают все более высокие стратиграфические и гипсометрические уровни в разрезе осадочного чехла. Наиболее явно они проявляются в диапазоне от пермско-триасового до нижнемелового комплексов вплоть до экспозиции их сохранившихся от эрозии останцов (даек, силлов и др.) на поверхности дна моря [6-8] вблизи архипелага ЗФИ. В пределах самого архипелага наблюдаются хорошо сохранившиеся в рельефе гребни даек (к тому же отчетливо читаемые на космоснимках), а также покровы и, кроме того, в многочисленных обнажениях (в том числе и Шпицбергена) - силлы, частые пластовые тела которых вскрыты скважинами, а нередко венчают разрезы и бронируют отложения от размыва.
Предположения о том, что «аномальные сейсмические горизонты» в разрезе осадочного чехла Восточно-Баренцевского бассейна обусловлены базальтоидными интрузиями, были высказаны около тридцати лет назад в [2; 3]. Однако геологическое подтверждение они получили только после того, как Лудловской скважиной (в центральной части Восточно-Баренцевского мегапрогиба) были вскрыты в разрезе триаса два самых верхних прослоя базальтов [9]. Изучение показало, что силлы представлены преимущественно габбро-диабазовыми и габбро-долеритовыми породами. По химическому составу они аналогичны трапповым образованиям архипелагов Земля Франца-Иосифа и Шпицберген.

Таким образом, по результатам анализа геологических и геофизических данных представилась возможность оконтурить ареал Баренцевоморской магматической провинции (см. рис. 1). В плане она имеет близкую к Т-образной конфигурацию с размахом с юга на север около 1300-1400 км, а с запада на восток (от Западного Шпицбергена до желоба Святой Анны) - около 1300 км. Площадь провинции по приближенным подсчетам составляет порядка 800000 км². Интервал насыщения интрузиями разреза только верхнепалеозойско-триасового осадочного чехла колеблется от 1 км по периферии провинции до 6-8 км (а возможно, и более) в депоцентре Восточно-Баренцевского бассейна. При этом следует отметить, что мощность пластовых тел 


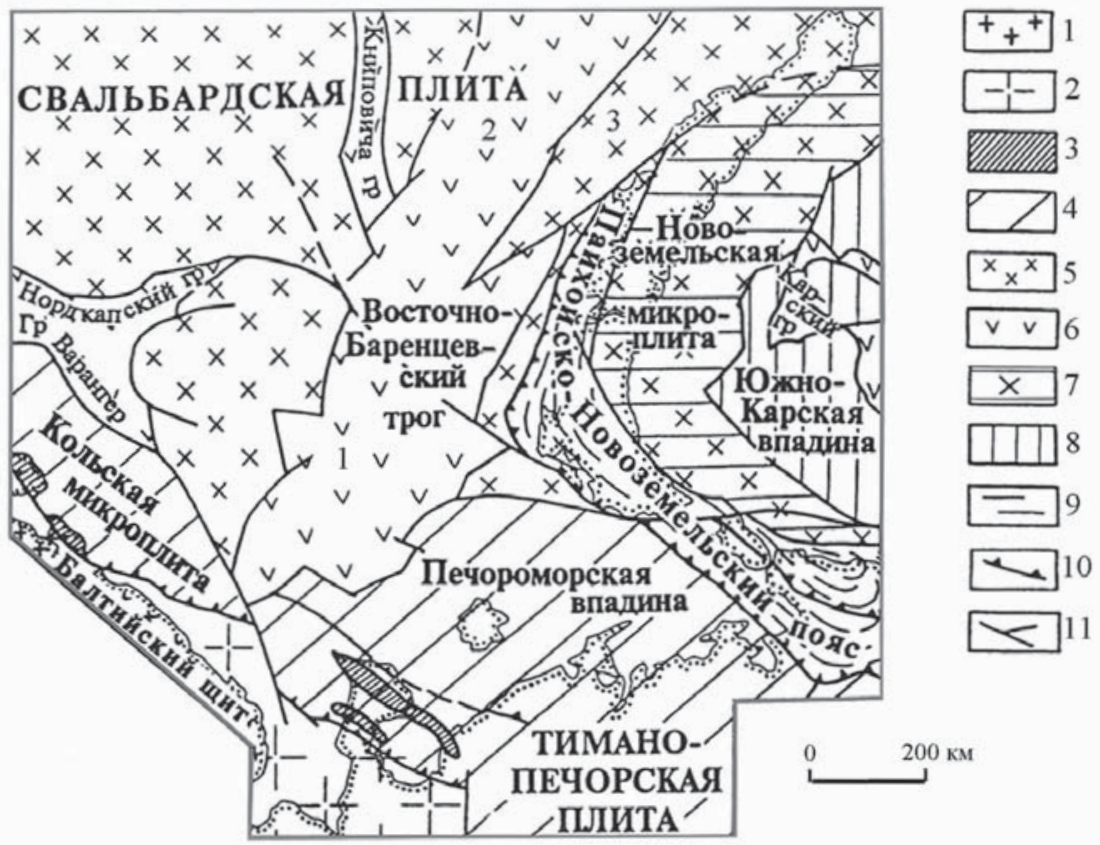

Рис. 2. Тектоническая схема юго-востока Баренцевоморской континентальной окраины и прилегающих областей по [5] с изменениями. Восточно-Баренцевский трог (мегабассейн): 1 - Южно-Баренцевская впадина, 2 - Северо-Баренцевская впадина; 3 - Адмиралтейское поднятие.

Условные обозначения: 1 - фундамент Балтийского щита, 2 - протерозойский фундамент Русской плиты, 3 - складчатые рифейско-вендские комплексы, 4 - эпибайкальские плиты, 5 - эпигренвильская плита, 6 - разновозрастные троги и грабены («гр» на схеме), 7 - эпигренвильская плита, затронутая киммерийскими дислокациями, 8 - эпигерцинская плита, 9 - раннекиммерийские складчатые структуры, 10 - надвиги, 11 - сбросы и сдвиги

базальтов изменяется от нескольких до десятков и сотен метров, судя по их обнажениям и результатам бурения параметрических скважин на островах архипелагов Шпицберген и ЗФИ [10]. С большой вероятностью можно говорить о том, что количество базальтовых тел в разрезе осадочного чехла увеличивается от периферии (остров Западный Шпицберген) к Хинлопенской зоне разломов и прогибов и особенно к центру провинции (архипелаг ЗФИ), где зафиксированы и покровы. Число пластов базальтов может достигать здесь по меньшей мере нескольких десятков. Учитывая общую мощность палеозойско-юрского осадочного выполнения в ВосточноБаренцевском бассейне (около 17-18 км), здесь можно ожидать их более значительного количества.

Относительно тектонической приуроченности проявлений мезозойского магматизма Баренцевоморской провинции отметим следующее. Магматические тела тяготеют преимущественно к областям деструкции литосферы - разломным зонам различного порядка и различной кинематики, сопровождающим формирование разномасштабных рифтовых бассейнов. Вместе с тем платобазальтовый магматизм в регионе получил интенсивное развитие в пределах сводово-блоковых поднятий, венчаемых архипелагами ЗФИ и Шпицберген. На северной оконечности Новой Земли дайки секут раннекиммерийские складчатые деформации [11]. Все это подчеркивает разнообразие тектоно-геодинамических обстановок, в которых проявлялся магматизм, обусловленный действием юрско-мелового плюма.

Из анализа полученных нами ${ }^{40} \mathrm{Ar} /{ }^{39} \mathrm{Ar}$ данных [12] вытекает, что на архипелаге ЗФИ существуют три группы сближенных значений итоговых возрастов базальтоидных образований. Они укладываются в следующие интервалы: первая - 196,5 £ 6,3$189,1 \pm 11,4$ млн лет (ранняя юра: геттанген плинсбах), вторая $-158,4 \pm 5,4-152,6 \pm 14,5$ млн лет (поздняя юра: оксфорд - кимеридж), третья $-138,1 \pm 2,6-125,2 \pm 5,5$ млн лет (ранний мел: валанжин - баррем-апт).

В последнюю возрастную группу входят и силлы западной части Земли Норденшельда (остров Западный Шпицберген), где по нашим определениям (по пироксену) они имеют возраст $133 \pm 4,3$ и 132,9 \pm 1,4 млн лет (оба готерив).

Полученные нами данные показывают, что раннеюрский магматизм на архипелаге ЗФИ последовал после завершения двух знаменательных тектоногеодинамических событий в Баренцевоморском регионе. Первое - это феномен позднепермскотриасового быстрого погружения Восточно-Баренцевского мегабассейна, опережающего по темпам лавинную седиментацию, приведшую к накоплению гигантской (10-11 км) линзы терригенных отложений. Вероятно, это событие ускорило проявление начального этапа излияний базальтов (обусловленного подъемом плюма), который можно рассматривать 


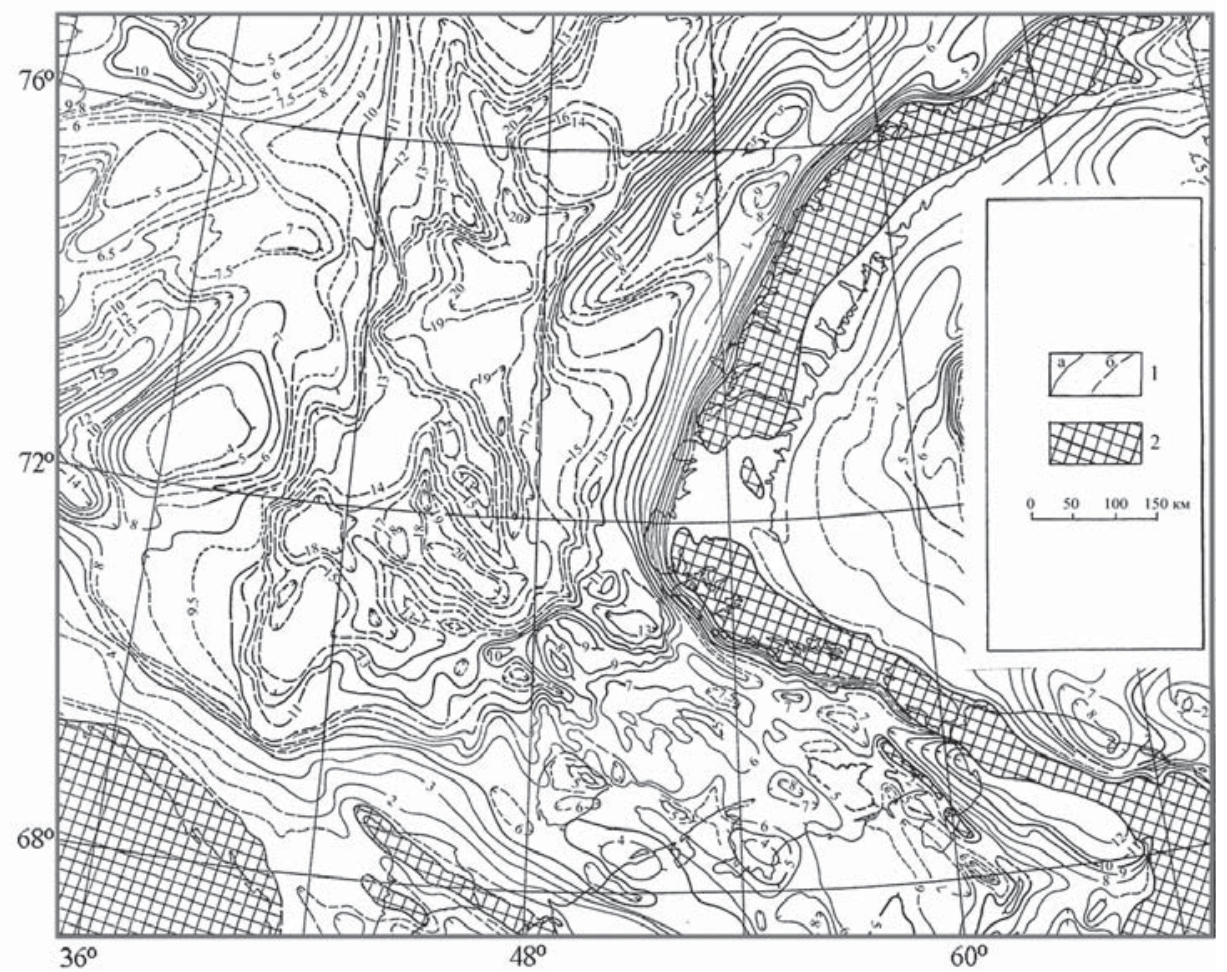

Рис. 3. Схема изогипс подошвы осадочного чехла. 1 - изогипсы (км): а - основные, б - дополнительные; 2 - выходы складчатого и кристаллического основания

как компенсационный (в ответ на быстрое погружение). Второе событие - это формирование Новоземельского складчато-надвигового пояса [11; 13]. Но наиболее значительный магматизм на ЗФИ по объему и разнообразию форм его проявления связывается с интервалом валанжин - апт (ранний мел), соответствующим основному этапу раскрытия Канадского океанического бассейна.

Представленные результаты в сопоставлении с известными данными о возрасте базальтоидов Канадского Арктического архипелага, севера Гренландии и Новосибирских островов свидетельствуют, что наиболее ранние проявления базальтоидного магматизма (ранняя юра), обусловленные начальным этапом действия плюма, имели место на архипелаге ЗФИ. Именно в этом районе Баренцевоморской континентальной окраины находился центр магматической активности. При этом магматизм на ЗФИ мог продолжаться по сеноман (рубеж 95 млн лет) включительно. Всплывающий здесь плюм привел к куполообразному подъему литосферы архипелага, его растрескиванию и поддержанию в приподнятом состоянии в течение около 100 млн лет. На этом отрезке времени описываемый плюм (названный нами Баренцевско-Амеразийским), растекаясь под литосферой, формировал сначала Баренцевоморскую магматическую провинцию, затем спрединговый центр в Канадском бассейне, а самыми молодыми и затухающими генерациями магматизма были охвачены периферийные части этого океанического бассейна - его палеоконтинентальные окраины.
Говоря об общегеодинамической обстановке, следует отметить, что во время раскрытия Канадского бассейна его спрединговый центр через окраинноконтинентальную трансформу и район архипелага ЗФИ мог совместиться по простиранию с депоцентром Восточно-Баренцевской троговой системы на палеоокраине Баренцевоморского региона. Поэтому значительный объем базальтоидного магматизма сосредоточился не только вдоль трансформной континентальной окраины, но и был внедрен в гигантскую по мощности линзу осадочных отложений ВосточноБаренцевского мегабассейна. В этой связи базальтоидный магматизм, учитывая его объем и временной отрезок проявления, может рассматриваться как своеобразный природный «термоэлемент», разогревающий осадочное выполнение бассейнов.

\section{Базальтоидный магматизм \\ и месторождения углеводородов}

Восточно-Баренцевский мегабассейн в тектоническом отношении представляет собой протяженную (около 1500 км) клинообразную (с размерами в поперечнике от около 500 до 300 км) структуру, рассекающую окраинно-континентальную платформу с севера на юг и утыкающуюся в систему перикратонных опусканий Восточно-Европейской платформы на траверзе Балтийского щита (рис. 2).

Мощность его палеозойско-мезойского осадочного выполнения точно не установлена, но по комплексу геолого-геофизических данных может превышать 20 км (рис. 3) [3-5; 14; 15 и др.]. При этом только на верхнепермско-мезозойскую часть разреза 


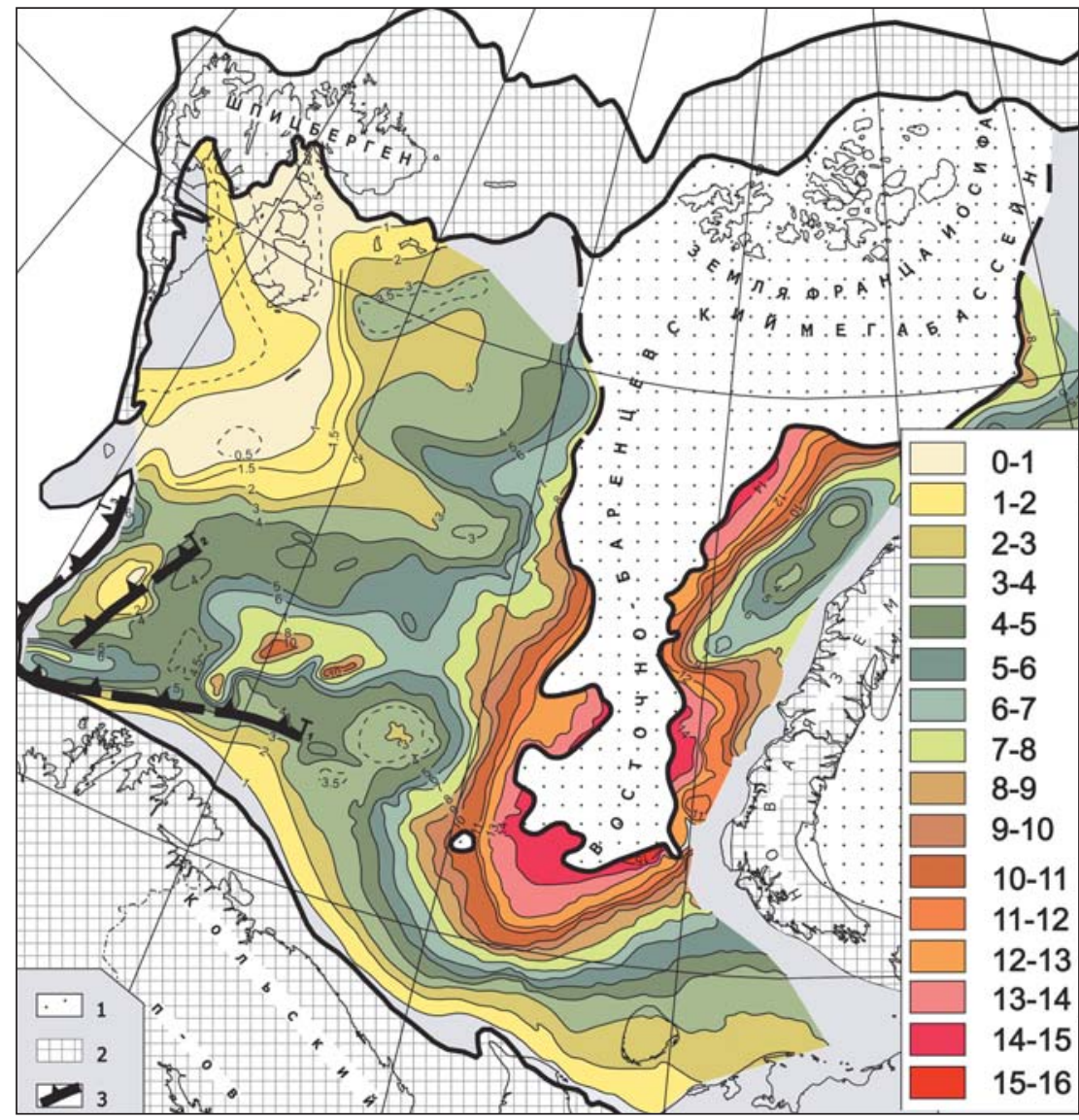

Рис. 4. Структурная карта по поверхности (кровле) позднепалеозойских карбонатов (изогипсы отражающего горизонта 1а): 1 - область фрагментарного и неуверенного прослеживания сейсмического отражающего горизонта 1а по причине экранирующего эффекта силлов либо замещения карбонатов терригенными отложениями, 2 - области эрозии или отсутствия верхнепалеозойских карбонатов, 3 - положение бровки шельфа в раннем, среднем и позднем триасе

приходится около 14 км (рис. 4), из которых 11 км представлены верхнепермско-триасовыми исключительно терригенными отложениями. Подстилающий палеозойский комплекс сложен терригенно-карбонатными и карбонатными толщами.

Размеры бассейна и наличие столь гигантской линзы осадочных отложений позволило многим исследователям предполагать обнаружение в нем весьма значительных по запасам месторождений углеводородов. И эти прогнозы подтверждены открытием в южной половине мегабассейна пока пяти месторождений УВ, причем только газоконденсатных и газовых, приуроченных к мезозойским комплексам (рис. 5) [16-18 и др.].

Два газовых месторождения - Мурманское (по запасам относится к крупным) и Северо-Кильдинское (по запасам среднее) - расположены на югозападной периферии Южно-Баренцевской впадины в пределах бортовых или прибортовых зон. Продуктивными являются триасовые отложения.

Другая группа месторождений связана с так называемым Лудловским (или Штокманско-Лунинским) порогом (поднятием) [16], разделяющим Южно- и Северо-Баренцевскую впадины (см. рис. 1 и 5). Газоконденсатные месторождения Штокманское и Ледовое относятся к уникальным по запасам, а Лудловское газовое месторождение - к крупным. Продуктивными здесь являются юрские отложения.

Нефтегазоматеринскими породами как для первой группы, так и для второй служат, как считается, пермско-триасовые отложения, а для последней, возможно, и нижнеюрские, гумусовые и сапропелевые по содержанию органического вещества, породы.

Особый и пристальный интерес вызывает вторая группа месторождений, расположенная в пограничной приподнятой зоне между двумя впадинами (см. рис. 1 и 5), 一 как с экономической точки зрения, так и с геологических позиций в плане дальнейших поисков аналогов и выяснения набора факторов, ответственных за их формирование. Этим вопросам посвящен ряд публикаций (см. [6] и ссылки в ней), в которых с различных позиций и с той или иной степенью обоснованности характеризуются причины, приведшие к столь гигантским концентрациям УВ скоплений.

Каковы в этой связи определяющие черты геологического строения и другие особенности, присущие 


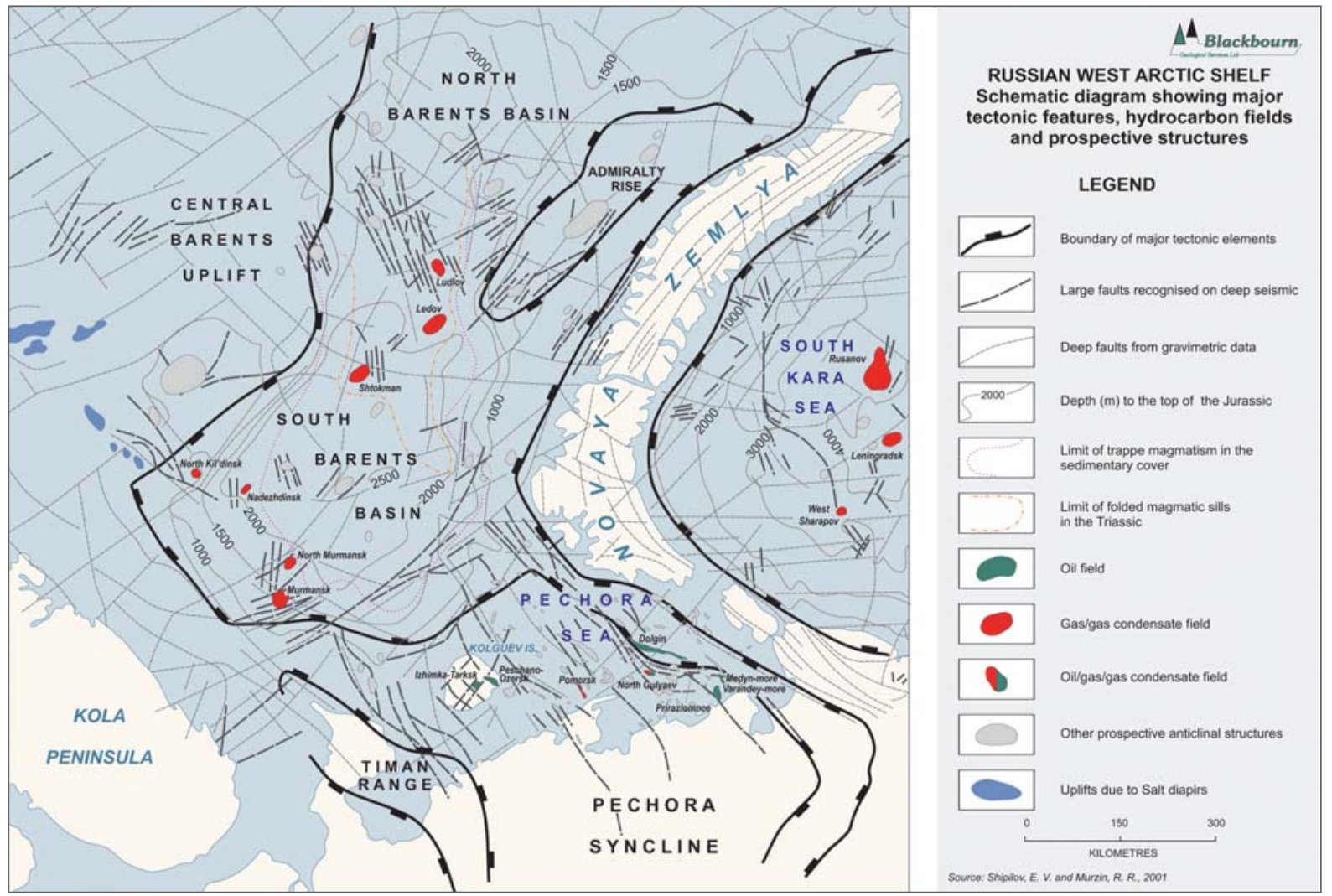

Рис. 5. Структурно-тектоническая схема и месторождения углеводородов Баренцево-Карского шельфа ([18], сайт Blackbourn Reports)

месторождениям Лудловского (Штокманско-Лунинского) поднятия?

Прежде всего следует отметить, что все антиклинальные локальные структуры-ловушки, с которыми связаны месторождения УВ, довольно отчетливо выражены как в меловых и триасовых отложениях, так и в рельефе кровли юрских образований (отражающий сейсмический горизонт В) с амплитудами около 100-200 м. Они изометричны в плане и по замкнутым изогипсам характеризуются площадью от 500 до 1500 км² [16; 18; 19]. Простирание складок Штокманского и Ледового месторождений северо-восточное, а Лудловского субширотное. В этой связи следует заметить, что в структурном плане кровли юрских отложений Штокманско-Лунинского поднятия преобладает система частых нарушений северо-западного простирания, совпадающая с направлением Байдарацкой зоны разломов, тогда как нарушения северо-восточной ориентировки имеют явно подчиненное значение. Изучение строения бассейна показывает, что и те, и другие связаны с разломами глубинного уровня заложения либо оперяют их $[5 ; 11 ; 20]$.

Продуктивность связана с песчано-алевритовыми породами среднекелловейского, байоского и ааленского возраста. Залежи всех трех месторождений пластово-сводовые и в разрезе изолированы друг от друга толщами глин. Мощность продуктивных горизонтов изменяется от 12-50 м на Ледовом месторождении до 30-40 м на Лудловском и достигает 80-90 м на Штокманском. При этом максимальная пористость коллекторов составляет соответственно 17-21\%, 25-27\% и 19-27\% [5; 17].

Газ всех продуктивных толщ в целом однотипен по составу (см. [9] и ссылки в ней). Так, газ Штокманского месторождения по составу компонентов является метановым (92,4-96,3\%), низкоазотным (1,7-2,5\%), бессернистым, низкоуглекислым (0,20,7\%), низкогелиеносным (0,017\%). Сверху вниз по разрезу месторождения отмечается утяжеление газа $(0,578-0,605$ г/см³).

Конденсат малосмолистый, малосернистый с плот-

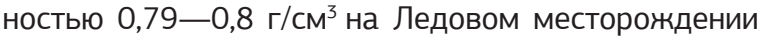

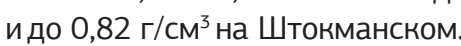

Сравнивая строение этих трех месторождений, можно заметить, что в северном направлении происходит усложнение их структуры за счет тектонической нарушенности. В этой связи наблюдается не только усложнение строения самих залежей (экранирование нарушениями, замещение коллекторов слабопроницаемыми породами), но и ухудшение качества регионального неокомского флюидоупора, представленного аргиллитистыми породами мощностью около $60 \mathrm{M}$.

Перечисленные характеристики и параметры в том или ином виде фигурируют в качестве главных 

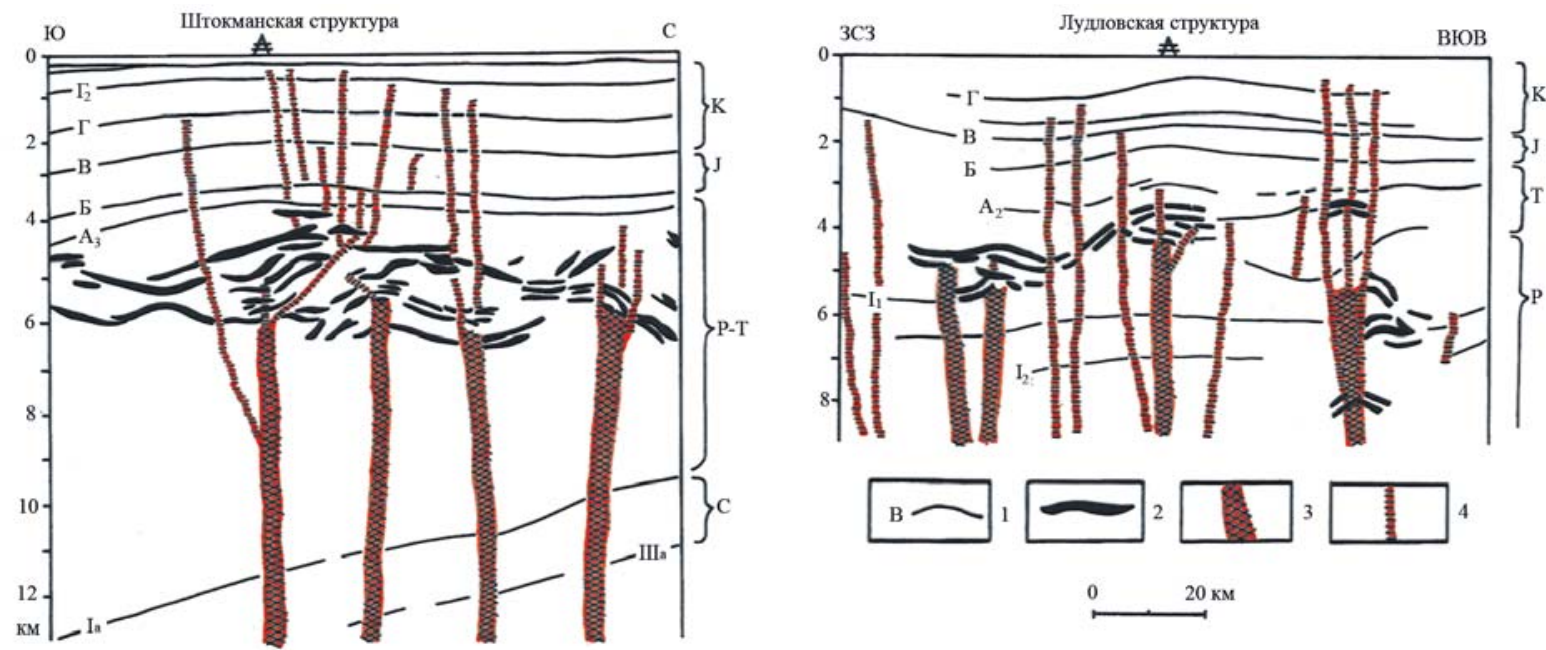

Рис. 6. Геолого-геофизические разрезы через Штокманскую и Лудловскую структуры [19]: 1 - основные опорные отражающие горизонты, 2 - пластовые тела - силлы (выделены без соблюдения вертикального масштаба), 3 - магмоподводящие каналы, 4 - разломы и зоны трещиноватости

факторов, определяющих масштабы месторождений УВ. Все эти показатели, бесспорно, являются необходимыми, но вместе с тем, как представляется, далеко не единственными при оценке условий нефтегазоносности и зависят от целого ряда других факторов.

В 1995 г. мы опубликовали работу [9], в которой по результатам сейсмостратиграфического анализа высказали мнение о формировании структур месторождений-гигантов Баренцева моря под воздействием внедрения силлов и о возможной связи с этим явлением фазового состава УВ. В дальнейшем в ходе геологических и геофизических исследований Баренцевоморского шельфа наши доводы нашли подтверждение. А в 2016 г. к аналогичным выводам о термогенном воздействии силлов на вмещающие породы и в этой связи их газогенерирующем потенциале пришли и норвежские коллеги [21].

В данной работе автор акцентирует внимание на тектоно-геодинамической стороне проблемы. Именно тектоно-геодинамические обстановки являются тем каркасом, на фоне которого развиваются те или иные палеогеографические и палеофациальные ситуации. Эти вопросы либо слабо освещены в публикациях, либо в силу различных причин упущены из виду или попросту не учитываются как не имеющие отношения к нефтегазовой геологии.

Обычно при характеристике и иллюстрации строения месторождения рассматриваются лишь комплексы пород, которые вскрыты бурением. Залегающая ниже часть разреза, уже после открытия месторождений хотя и освещенная сейсморазведкой, чаще всего выпадает из поля зрения. А между тем, если судить по материалам МОВ ОГТ (метода отраженных волн общей глубинной точки), антиклинальные поднятия отмеченных выше месторождений не имеют соответствия в подстилающих допозднетриасовых отложениях [18; 19]. Опорные отражающие горизонты, относимые к средне-верхнепалезойскому комплексу под рассматриваемыми структурами, залегают субгоризонтально либо моноклинально (рис. 6). При этом видимого углового несогласия между верхнепалеозойскими и мезозойскими отложениями не зафиксировано. Вместе с тем на сводовых частях рассматриваемых структур отмечаются следы размыва, начавшегося по меньшей мере в конце юры - начале мела, а возможно, и несколько раньше. Это несомненно свидетельствует о том, что к позднеюрско-раннемеловому времени (неоком) в структурном плане данные поднятия уже существовали и продолжали расти. Если так, то можно говорить о том, что с этого периода началось формирование месторождений и заполнение ловушек УВ флюидами.

В связи с отмеченными сейсмостратиграфическими особенностями разреза в отношении рассматриваемых крупнейших структурных ловушек УВ сложились представления о них как о бескорневых [22]. В одних случаях причиной их формирования называлась специфика условий седиментации, в других тангенциальное воздействие затухающего фронта надвигообразования со стороны Новоземельского орогена.

Сейсмостратиграфический анализ показывает, что в комплексах осадочного чехла Восточно-Баренцевского мегабассейна широкое развитие получили специфические отражающие горизонты, геологическая природа которых долгое время была неясной. Их изучение и последующее бурение установили магматическую природу аномальной сейсмической записи, обусловленной пластовыми интрузиями основного состава [9]. Среди них преобладают пакеты силлов. Ареал проявления этого базальтоидного магматизма, как показано выше, охватывает архипелаги Шпицберген, Земля Франца-Иосифа, северную оконечность Новой Земли, прилегающий к ним 


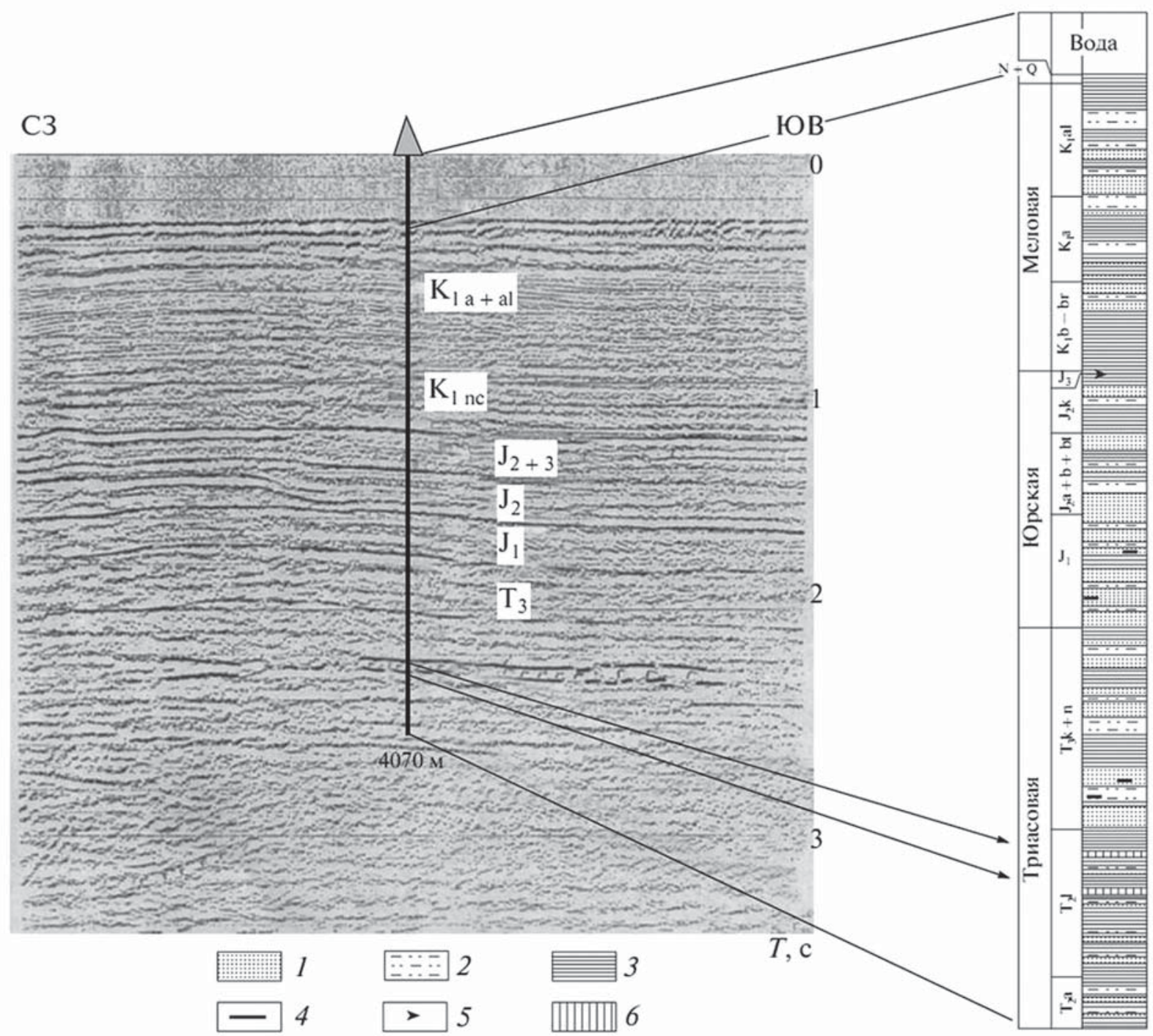

Рис. 7. Сопоставление сейсмического разреза (фрагмент профиля 088513) Лудловской площади и разреза скважины, вскрывшей пластовые тела силлов в терригенном разрезе триаса $[1 ; 6]$. Стрелками показано положение силлов в разрезе скважины. Литологический состав: 1 - песчаники, 2 - алевролиты, 3 - глины, аргиллиты, 4 - угленосность, 5 - битуминозные аргиллиты, 6 - базальты

шельф и занимает к югу практически всю площадь Восточно-Баренцевской троговой системы.

На архипелагах ЗФИ и Шпицберген пластовые тела базальтоидов вскрыты рядом скважин, причем их число в разрезе может достигать нескольких десятков [10].

Многочисленные тела силлов в триасовых отложениях отмечаются на сейсмических разрезах, пересекающих Штокманско-Лунинский порог, в том числе и под локальными структурами месторождений УВ - Штокманского, Ледового и Лудловского (рис. 7 и 8). Под этими антиклинальными поднятиями пакеты силлов образуют как бы подушкообразные раздувы за счет увеличения числа пластовых тел (см. рис. 6). Судя по результатам бурения на архипелагах Земля Франца-Иосифа и Шпицберген, толщина пластовых тел базальтов может колебаться от нескольких до десятков метров. Тогда с учетом их числа суммарная мощность базальтовых прослоев примерно соответствует амплитуде рассматриваемых локальных поднятий по кровле юры. Условия залегания отдельных тел силлов различны: иногда они залегают согласно с вмещающими породами, чаще несогласно, пересекая различные стратиграфические уровни осадочного чехла. Бурением на Лудловской структуре были вскрыты два самых верхних пласта габбро-диабазов, залегающих в верхней половине разреза триаса (см. рис. 7). Как показало определение их абсолютного возраста K-Ar методом, они принадлежат к разным генерациям: верхний силл имеет возраст 131-139 млн лет (неоком: готерив-валанжин), а второй, расположенный на 143 м ниже, - 159 млн лет (оксфорд). Мощность этих пластов базальтов оценивается соответственно в 27 и 5 м [9].

Новейшие определения абсолютного возраста отобранных нами на островах Земли Франца-Иосифа образцов пород трапповой формации ${ }^{40} \mathrm{Ar} /{ }^{39} \mathrm{Ar}$ 


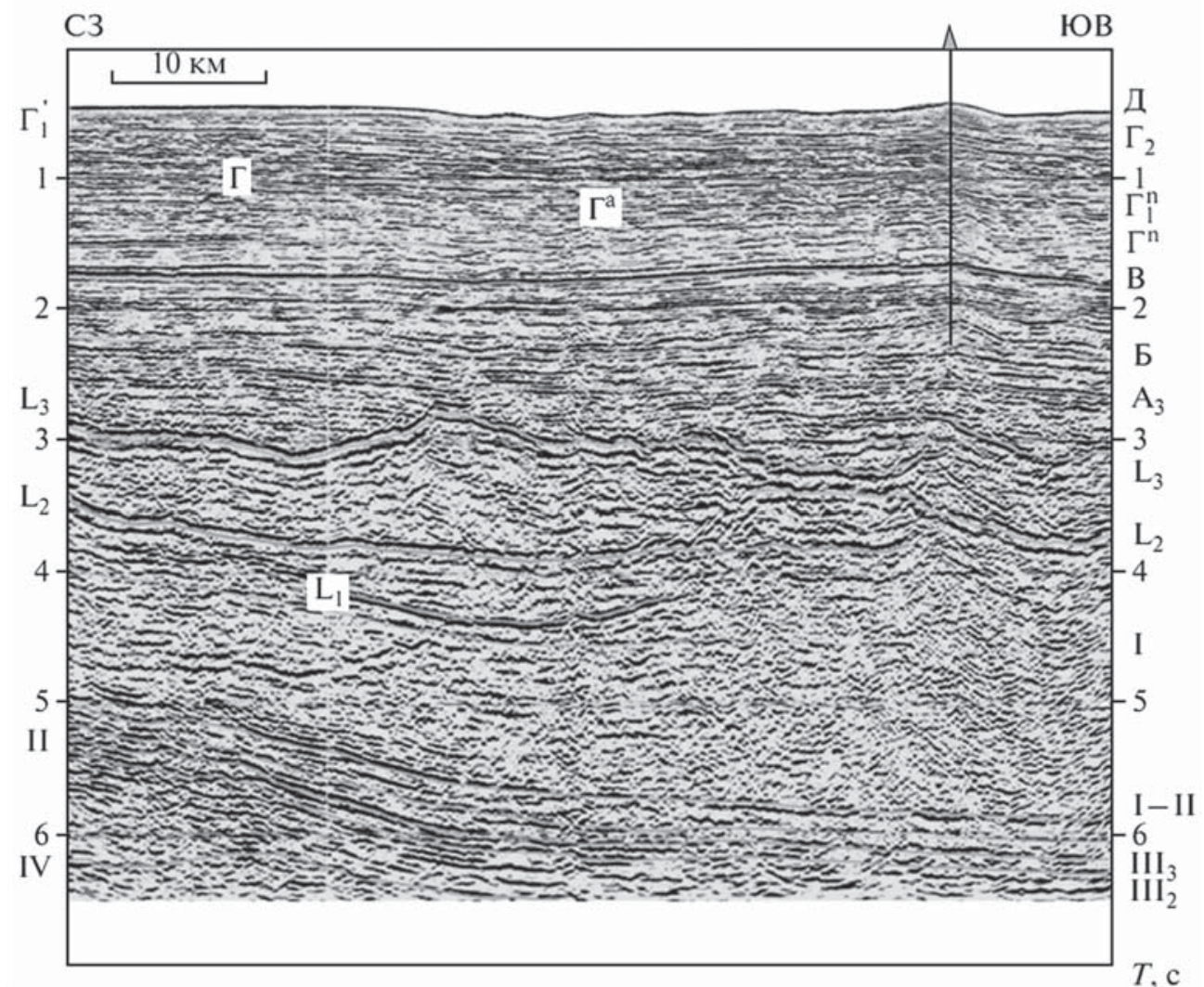

Рис. 8. Фрагмент сейсмического разреза по профилю 89000 с положением скважины, иллюстрирующий распространение и поведение базальтовых пластов под Штокманской структурой (отражающие сейсмические горизонты группы L) [14]. Индексы по бокам разреза - основные отражающие горизонты в осадочном чехле: Д - кровля меловых отложений, Г (группа горизонтов) - отражения от границ в меловых отложениях, В - кровля юры, Б - кровля триаса, А - граница нижнего и среднего триаса, I - граница триаса и перми, I- II - граница перми и карбона, II - граница вблизи раздела среднего и нижнего карбона, III ${ }_{3}$ - граница фамена и франа, III, - подошва франа, IV - подошва девона

методом показали более широкий разброс его значений - от 125 до 189 млн лет [12].

Таким образом, результаты сейсмостратиграфического анализа и определения возраста проявлений базальтоидного магматизма с большой вероятностью указывают на то, что формирование и рост локальных структур рассматриваемых месторождений УВ, как, впрочем, и самого Штокманско-Лунинского порога, и процесс интрузивной магматической деятельности протекали практически одновременно.

\section{Обсуждение и заключение}

Говоря о площадном распространении и влиянии юрско-мелового базальтоидного магматизма на вмещающие породы рассматриваемой континентальной окраины, следует заметить, что помимо геолого-геофизических материалов, использованных в данной работе, есть и другие, независимые результаты исследований, свидетельствующие даже о более широком воздействии этого эндогенного фактора. В [23] на основе палеомагнитных исследований приводятся доказательства того, что в фанерозойское время восточная часть Фенноскандинавского щита не только испытала влияние девонской тектономагматической активизации, но и подверглась термальному воздействию мезозойского плюмового магматизма. Об этом свидетельствуют значительные масштабы мезозойского перемагничивания даек баренцевоморского побережья и других интрузий Кольского полуострова, большинство которых имеют девонские изотопные датировки.

Изложенное позволяет заключить, что юрско-меловой тектономагматический этап имел определяющее значение в создании условий для размещения месторождений, а следовательно, и УВ потенциала Лудловского (Штокманско-Лунинского) поднятия. Проведенный в этом отношении анализ геолого-геофизического материала позволяет высказать следующие соображения:

- для рассматриваемых антиклинальных структур, к которым приурочены гигантские газоконденсатные месторождения, причиной формирования являлся тектономагматический фактор, т. е. внедрение силлов;

- преобладающий фазовый состав флюидов указанных месторождений и их громадный по запасам потенциал в отличие от других нефтегазоносных структур Баренцевоморского региона во многом определялся влиянием термальных процессов базальтоидного магматизма на газогенерационные свойства вмещающих пород верхнепермско-триасового и более древнего возраста; 


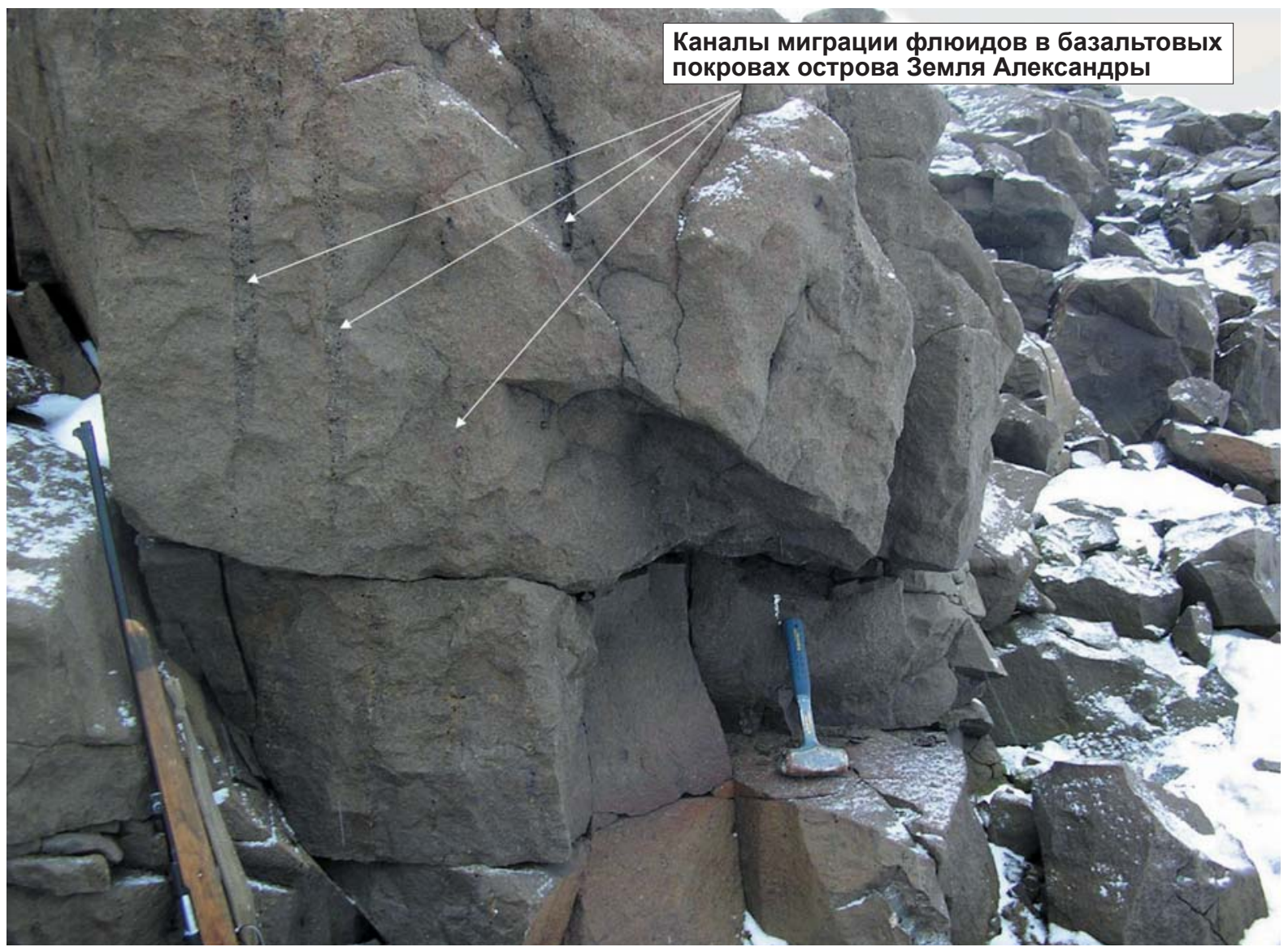

Рис. 9. Каналы миграции флюидов в базальтовых покровах острова Земля Александры, архипелаг Земля Франца-Иосифа (фото Э. В. Шипилова)

- магмоподводящие каналы, разломы и зоны трещиноватости могли служить активными каналами миграции УВ флюидов (рис. 9), участвуя в «подкачке» и заполнении структурных ловушек;

- учитывая широкое развитие пластовых тел базальтов в плане и по разрезу, они могут быть промежуточными флюидоупорами для УВ, что не исключает возможности обнаружения месторождений-спутников.

В этой связи следует отметить, что архипелаг Земля Франца-Иосифа с его масштабами магматизма может служить природной лабораторией для изучения термического воздействия траппов на генерирующие свойства осадочных комплексов в связи с оценкой углеводородного потенциала не только этого района, но и всего Восточно-Баренцевского мегабассейна, учитывая уже известные находки битумопроявлений [24-26].

Такие исследования проводились сибирскими геологами в Тунгусской синеклизе и показали, что современный облик не только структуры осадочного чехла, но и нефтегазоносности Сибирской платформы был сформирован под воздействием пермскотриасового траппового магматизма. Установлено, что в результате его проявления была сформирована специфическая зональность в распределении УВ флюидов, нарушающая обычную закономерность, а также зафиксированы изменения в составе нафтидов [27-30].

Исследование выполнено при финансовой поддержке РФФИ в рамках научного проекта № 18-0570012, код «Ресурсы Арктики».

\section{Литература}

1. Шипилов Э. В. О периодичности проявлений основного магматизма в пределах Западно-Арктической окраины Евразии в фанерозое // Вестн. МГТУ: Тр. Мурм. гос. техн. ун-та. - 1998. - Т. 1, № 3. - С. 97-104.

2. Маргулис Л. С. О геологической природе аномальных отражающих горизонтов в триасовых отложениях Баренцева моря // Докл. Акад. наук. 1986. - Т. 290, № 1. - С. 184-187.

3. Шипилов Э. В., Моссур А. П. Об аномальных сейсмических горизонтах в осадочном чехле Баренцева моря // Геотектоника. - 1990. — № 1. - С. 90-97. 4. Shipilov E. V., Mossur A. P. The structure of the sedimentary section at depth in the Arctic region // Intern. Geology Rev. - 1991. - Vol. 33, № 1. - P. 92-102.

5. Объяснительная записка к Тектонической карте Баренцева моря и северной части Европейской России: Масштаб 1:2 500000 / В.И.Богацкий, 
Н. А. Богданов, С. Л. Костюченко и др. - М.: Ин-т литосферы РАН, 1996. - 94 с.

6. Шипилов Э. В. Позднемезозойский магматизм и кайнозойские тектонические деформации Баренцевоморской континентальной окраины: влияние на распределение углеводородного потенциала // Геотектоника. - 2015. - № 1. - С. 60-85.

7. Solheim A., Musatov E., Heintz N. Geological aspects of Franz Josef Land and the northern Barents Sea. — Oslo: Norsk Polarinstitutt, 1998. - 120 p. — (Meddelelser № 151).

8. Соколов С. Ю., Абрамова А. С., Зарайская Ю. А. и Әр. Процессы эволюции литосферы в районе архипелага Земля Франца-Иосифа по данным картирования донных обнажений магматических тел // Мониторинг. Наука и технологии. - 2016. - № 4 (29). - С. 14-19.

9. Комарницкий В. М., Шипилов Э. В. Новые геологические данные о магматизме Баренцева моря // Докл. Акад. наук. - 1991. - Т. 320, № 5. - С. 1203-1206. 10. Dibner V. D. Geology of Franz Josef Land. - Oslo: Norsk Polarinstitutt, 1998. - 190 p. — (Meddelelser № 146).

11. Кораго Е. А., Тимофеева Т. Н. Магматизм Новой Земли (в контексте геологической истории Баренцево-Северокарского региона). - СПб.: ВНИИОкеангеология, 2005. - 225 с.

12. Шипилов Э. В., Карякин Ю. В. Баренцевоморская магматическая провинция: геолого-геофизические свидетельства и новые результаты определения Ar39/Ar40 возраста // Докл. Акад. наук. - 2011. T. 439, № 3. - C. 376-382.

13. Богданов Н. А., Хаин В. Е., Шипилов Э. В. Раннемезозойская геодинамика Баренцево-Карского региона // Докл. Акад. наук. - 1997. - Т. 357, № 4. - С. $511-515$.

14. Шипилов Э. В., Шкарубо С. И. Современные проблемы геологии и тектоники осадочных бассейнов Евразиатско-Арктической континентальной окраины. - Т. 1: Литолого- и сейсмостратиграфические комплексы осадочных бассейнов Баренцево-Карского шельфа. - Апатиты: Изд-во КНЦ РАН, 2010. - 266 с.

15. Шкарубо С. И., Шипилов Э. В. Тектоника Западно-Арктической платформы // Разведка и охрана недр. — 2007. — № 9. - С. 32-47.

16. Борисов А. В., Таныгин И. А., Винниковский В. С., Борисова И. А. Штокмановско-Лунинский структурный порог Баренцевоморского шельфа - новый крупный нефтегазоносный район России // Геология нефти и газа. - 1995. - № 7. - С. 10-15.

17. Шипилов Э. В., Боголепов А. К. Распределение нефтегазоносности и пористости в продуктивных отложениях Южно-Баренцевского бассейна // Докл. Акад. наук. - 1997. - Т. 355, № 2. С. $238-240$.
18. Шипилов Э. В., Мурзин Р. Р. Месторождения углеводородного сырья западной части российского шельфа Арктики: геология и закономерности размещения // Геология нефти и газа. - 2001. № 4. - C. 6-19.

19. Шипилов Э. В., Юнов А. Ю. О генезисе антиклинальных структур месторождений углеводородов восточной части Баренцева моря // Докл. Акад. наук. - 1995. - Т. 342, № 1. - С. 87-88.

20. Каленич А. П., Морозов А. Ф., Орго В. В. u др. Магматизм и тектоника Вайгачско-Новоземельского орогена // Разведка и охрана недр. - 2005. - № 1. - С. 20-25.

21. Polteau S., Hendriks B., Planke S. et al. The Early Cretaceous Barents Sea Sill Complex: Distribution, 40Ar/39Ar geochronology, and implications for carbon gas formation // Palaeogeography, Palaeoclimatology, Palaeoecology. - 2016. - Vol. 441. - P. 83-95.

22. Осадочный чехол Западно-Арктической метаплатформы (тектоника и сейсмостратиграфия) / Под ред. Е. Ф. Безматерных, Б. В. Сенина, Э. В. Шипилова. - Мурманск: Север, 1993. - 184 с.

23. Веселовский Р. В., Арзамасцев А. А. Признаки мезозойской эндогенной активности в северо-восточной части Фенноскандинавского щита // Докл. Акад. наук. - 2011. - Т. 438, № 6. - С. 782-786.

24. Клубов Б. А., Острой А. С. О первых находках природных битумов на Земле Франца-Иосифа // Докл. Акад. наук. - 1995. - Т. 342, № 6. - С. 785-788. 25. Безруков В. М. Природные битумы о-ва ГреэмБелл Земли Франца-Иосифа и их значение для оценки перспектив нефтегазоносности арктической окраины Баренцево-Северокарского шельфа // Геология нефти и газа. - 1997. - № 2. - С. 20-25.

26. Клубов Б. А., Винокуров И. Ю., Гарибьян Е. В. Битумопроявления на о-ве Хейса // Геология нефти и газа. - 1997. - № 2. - С. 10-13.

27. Конторович А. Э., Мельников Н. В., Старосельцев В. С., Хоменко Н. В. Влияние интрузивных траппов на нефтегазоносность палеозойских отложений Сибирской платформы // Геология и геофизика. - 1987. - № 5. - С. 14-20.

28. Конторович А. Э., Филипцов Ю. А., Битнер А. К. и др. Кембрийские газы, нефти и конденсаты на Сибирской платформе в районах интенсивного развития траппового магматизма // Геология и геофизика. - 1996. - № 9. - С. 875-883.

29. Хоменко А. В. Влияние трапповых силлов на структуры осадочного чехла Тунгусской синеклизы // Тектоника платформенных областей. - Новосибирск: Наука, 1988. - С. 66-71.

30. Polyansky O. P., Reverdatto V. V., Sverdlova V. G. Convection of two-phase fluid in a layered porous medium driven by the heat of magmatic dikes and sills // Geochemistry Intern. - 2002. - Vol. 40, № 1. - P. 69-81.

\section{Информация об авторе}

Шипилов Эдуард Викторович, доктор геолого-минералогических наук, профессор, главный научный сотрудник, Полярный геофизический институт (183010, Россия, Мурманск, ул. Халтурина, 15), e-mail: shipilov@pgi.ru. 
Шипилов Э. В. Базальтоидный магматизм и проблема газоносности Восточно-Баренцевского мегабассейна // Арктика: экология и экономика. - 2018. - № 2 (30). — С. 94-106. DOI: 10.25283/2223-4594-2018-2-94-106.

\title{
BASALTOID MAGMATISM AND THE PROBLEM OF THE GAS POTENTIAL OF THE EAST-BARENTS MEGABASIN
}

Shipilov E. V.

Polar Geophysical Institute (Murmansk, Russian Federation)

\begin{abstract}
The manifestations of Jurassic-Cretaceous basaltic magmatism in the sedimentary cover of the Barents Sea continental margin have been fixed by various methods of geological and geophysical studies. Anomalous seismic horizons related to basaltic sills hosted in terrigenous sequences are traced in plan view as a tongue from Franz Josef Land Archipelago far to the south along the East Barents Trough System close to its depocentral zone with the transformed thinned earth's crust. The Barents Sea igneous province has been contoured. The results of seismic stratigraphy analysis and timing of basaltic rock occurrences indicate with a high probability that the local structures of the hydrocarbon fields and the Stockman-Lunin Saddle proper were formed and growth almost synchronously with intrusive magmatic activity.
\end{abstract}

Keywords: East-Barents megabasin, basalt magmatism, seismic sections, anticlinal structure, field of hydrocarbons, tectono-magmatic factor.

The study was performed with financial support RFBR, research project № 18-05-70012, code “Resources in the Arctic".

\section{References}

1. Shipilov E. V. O periodichnosti proyavlenii osnovnogo magmatizma v predelakh Zapadno-Arkticheskoi okrainy Evrazii v fanerozoe. [On the periodicity of the manifestations of basic magmatism within the Western Arctic margin of Eurasia during the Phanerozoic]. Vestn. MGTU: Tr. Murm. gos. tekhn. un-ta, 1998, vol. 1, no. 3, pp. 97-104. (In Russian).

2. Margulis L. S. O geologicheskoi prirode anomal'nykh otrazhayushchikh gorizontov $v$ triasovykh otlozheniyakh Barentseva morya. [Geological nature of anomalous reflectors in the Triassic sequences of the Barents Sea]. Dokl. Akad. nauk, 1986, vol. 290, no. 1, pp. 184-187. (In Russian).

3. Shipilov E. V., Mossur A. P. Ob anomal'nykh seismicheskikh gorizontakh $v$ osadochnom chekhle Barentseva morya. [On anomalous seismic horizons in the Barents Sea sedimentary cover. Geotectonic]. Geotektonika, 1990, no. 1, pp. 90-97. (In Russian).

4. Shipilov E. V., Mossur A. P. The structure of the sedimentary section at depth in the Arctic region. Intern. Geology Rev, 1991, vol. 33, no. 1, pp. 92-102.

5. Ob"yasnitel'naya zapiska k Tektonicheskoi karte Barentseva morya i severnoi chasti Evropeiskoi Rossii: Masshtab 1:2 500 000. [Explanatory Note to Tectonic Map of the Barents Sea and Russian Northern Eurasia. Scale1:2 500 000]. Vol. I. Bogatskii, N. A. Bogdanov, S. L. Kostyuchenko et al. Moscow, In-t litosfery RAN, 1996, 94 p. (In Russian).

6. Shipilov E. V. Late mesozoic magmatism and cenozoic tectonic deformations of the Barents sea continental margin: effect on hydrocarbon potential distribution. Geonectonics, 2015, vol. 49, no. 1, pp. 53-74.

7. Solheim A., Musatov E., Heintz N. Geological aspects of Franz Josef Land and the northern Barents Sea. Oslo, Norsk Polarinstitutt, 1998, 120 p. (Meddelelser no. 151). 8. Sokolov S. Yu., Abramova A. S., Zaraiskaya Yu. A. et al. Protsessy evolyutsii litosfery $v$ raione arkhipelaga Zemlya Frantsa-losifa po dannym kartirovaniya donnykh obnazhenii magmaticheskikh tel. [Lithosphere evolution of the Franz-Josef Land archipelago based on mapping the bottom denudations of magma bodies]. Monitoring. Nauka i tekhnologii, 2016, no. 4 (29), pp. 14-19. (In Russian).

9. Komarnitskii V. M., Shipilov E. V. Novye geologicheskie dannye o magmatizme Barentseva morya. [New Geological Data on the Magmatism of the Barents Sea]. Dokl. Akad. nauk, 1991, vol. 320, no. 5, pp. 12031206. (In Russian).

10. Dibner V. D. Geology of Franz Josef Land. Oslo, Norsk Polarinstitutt, 1998, 190 p. (Meddelelser no. 146).

11. Korago E. A., Timofeeva T. N. Magmatizm Novoi Zemli (v kontekste geologicheskoi istorii BarentsevoSeverokarskogo regiona). [Magmatizm of Novaya Zemlya in Context of Geological History of the Barents-North Kara Region]. St. Petersburg, VNIIOkeangeologiya, 2005, 225 p. (In Russian).

12. Shipilov E. V., Karyakin Yu. V. The Barents Sea igneous province: geological-geophysical evidence and new ${ }^{40} \mathrm{Ar} /{ }^{39} \mathrm{Ar}$ dates. Doklady Earth Sciences, 2011, vol. 439, no. 1, pp. 955-960. 
13. Bogdanov N. A., Khain V. E., Shipilov E. V. Early Mesozoic geodynamics of the Barents-Kara region. Doklady Earth Sciences, 1997, vol. 357A, no. 9, pp. 1285-1289.

14. Shipilov E. V., Shkarubo S. I. Sovremennye problemy geologii i tektoniki osadochnykh basseinov Evraziatsko-Arkticheskoi kontinental'noi okrainy. T. 1. Litologo- i seismostratigraficheskie kompleksy osadochnykh basseinov Barentsevo-Karskogo shel'fa. [Current issues of geology and tectonics of sedimentary basins of Eurasian-Arctic continental margin. Vol. 1. Lithologic- and seismostratigraphic complexes of sedimentary basins of the Barents-Kara shelf]. Apatity, Izd-vo KNTs RAN, 2010, 266 p. (In Russian).

15. Shkarubo S. I., Shipilov E. V. Tektonika ZapadnoArkticheskoi platformy [Tektonics of the West Arctic Platform]. Razvedka i okhrana nedr, 2007, no. 9, pp. 32-47. (In Russian).

16. Borisov A. V., Tanygin I. A., Vinnikovskii V. S., Borisova I. A. Shtokmanovsko-Luninskii strukturnyi porog Barentsevomorskogo shel'fa - novyi krupnyi neftegazonosnyi raion Rossii. [Stockman-Lunin structural threshold of the Barents Sea shelf: a new large petroliferous province in Russia]. Geologiya nefti i gaza, 1995, no. 7, pp. 10-15. (In Russian).

17. Shipilov E. V., Bogolepov A. K. Distribution of oil and gas potential and porosity in productive deposits of the South Barents Basin. Doklady Earth Sciences, 1997, vol. 355, no. 5, pp. 699-701.

18. Shipilov E. V., Murzin R. R. Mestorozhdeniya uglevodorodnogo syr'ya zapadnoi chasti rossiiskogo shel'fa Arktiki: geologiya i zakonomernosti razmeshcheniya. [Hydrocarbon fields in the western Russian Arctic shelf: Geology and localization]. Geologiya nefti i gaza, 2001, no. 4, pp. 6-19. (In Russian).

19. Shipilov E. V., Yunov A. Yu. O genezise antiklinal'nykh struktur mestorozhdenii uglevodorodov vostochnoi chasti Barentseva morya. [Genesis of anticlinal structures in hydrocarbon fields from eastern Barents Sea]. Dokl. Akad. nauk, 1995, vol. 342, no. 1, pp. 87-88. (In Russian).

20. Kalenich A. P., Morozov A. F., Orgo V. V. et al. Magmatizm i tektonika Vaigachsko-Novozemel'skogo orogena. [Magmatism and tectonics of the Vaigach-Novaya Zemlya Orogen]. Razvedka i okhrana nedr, 2005, no. 1, pp. 20-25. (In Russian).

21. Polteau S., Hendriks B., Planke S., Ganerød M., Corfu F., Faleide J., Midtkandal I., Svensen H., Myklebust $R$. The Early Cretaceous Barents Sea Sill Complex: Distribution, 40Ar/39Ar geochronology, and implications for carbon gas formation. Palaeogeography,
Palaeoclimatology, Palaeoecology, 2016, vol. 441, pp. 83-95.

22. Osadochnyi chekhol Zapadno-Arkticheskoi metaplatformy (tektonika i seismostratigrafiya). [Sedimentary Cover of the West Arctic Metaplatform (Tectonics and Seismic Stratigraphy)]. Pod red. E. F. Bezmaternykh, B. V. Senina, E. V. Shipilova. Murmansk, Sever, 1993, 184 p. (In Russian).

23. Veselovskii R. V., Arzamastsev A. A. Evidence for the Mesozoic endogenous activity in the northeastern part of the Fennoscandian Shield. Doklady Earth Sciences, 2011, vol. 438, no. 2, pp. 754-758.

24. Klubov B. A., Ostroi A. S. O pervykh nakhodkakh prirodnykh bitumov na Zemle Frantsa-losifa. [First findings of natural bitumen on Franz Josef Land]. Dokl. Akad. nauk, 1995, vol. 342, no. 6, pp. 785-788. (In Russian). 25. Bezrukov V. M. Prirodnye bitumy o-va Greem-Bell Zemli Frantsa-losifa i ikh znachenie dlya otsenki perspektiv neftegazonosnosti arkticheskoi okrainy Barentsevo-Severokarskogo shel'fa. [Natural bitumen on Graham Bell Island, Franz Josef Land and its implications for evaluation of petroleum resource potential of the Arctic margin of the Barents-North Kara shelf]. Geologiya nefti i gaza, 1997, no. 2, pp. 20-25. (In Russian).

26. Klubov B. A., Vinokurov I. Yu., Garib'yan E. V. Bitumoproyavleniya na o-ve Kheisa. [Bitumen occurrences on Heiss Island]. Geologiya nefti i gaza, 1997, no. 2, pp. 10-13. (In Russian).

27. Kontorovich A. E., Mel'nikov N. V., Starosel'tsev V. S., Khomenko N. V. Vliyanie intruzivnykh trappov na neftegazonosnost' paleozoiskikh otlozhenii Sibirskoi platformy. [Effect of intrusive traps on petroleum resource potential of Paleozoic rocks in the Siberian Platform]. Geologiya i geofizika, 1987, no. 5, pp. 14-20. (In Russian)

28. Kontorovich A. E., Filiptsov Yu. A., Bitner A. K. et al. Kembriiskie gazy, nefti i kondensaty na Sibirskoi platforme $v$ raionakh intensivnogo razvitiya trappovogo magmatizma. [Cambrian gases, oils, and condensates in the Siberian Platform in the areas of intense trap magmatism]. Geologiya i geofizika, 1996, no. 9, pp. 875-883. (In Russian).

29. Khomenko A. V. Vliyanie trappovykh sillov na struktury osadochnogo chekhla Tungusskoi sineklizy. [Effect of trap sills on sedimentary cover structure of the Tungus Syneclise]. Tektonika platformennykh oblastei. Novosibirsk, Nauka, 1988, pp. 66-71. (In Russian).

30. Polyansky O. P., Reverdatto V. V., Sverdlova V. G. Convection of two-phase fluid in a layered porous medium driven by the heat of magmatic dikes and sills. Geochemistry Intern. 2002, vol. 40, no. 1, pp. 69-81.

Information about the author

Shipilov Eduard Viktorovich, Doctor of Sciences, Professor, Chief Scientific Researcher, Polar Geophysical Institute (15, Khalturina st., Murmansk, Russia, 183010), e-mail: shipilov@pgi.ru.

\section{Bibliographic description}

Shipilov E. V. Basaltoid magmatism and the problem of the gas potential of the East-Barents megabasin. Arctic: ecology and economy, 2018, no. 2 (30), pp. 94-106. DOI: 10.25283/2223-4594-2018-2-94-106. (In Russian). 